\title{
Increasing the reproductive function of Large White boars
}

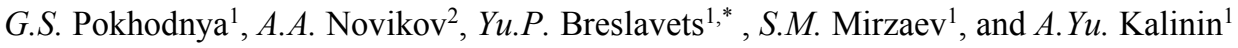 \\ ${ }^{1}$ Federal State Budgetary Educational Institution of Higher Education "Belgorod State Agrarian \\ University named after V.Ya. Gorin", vil. Maysky, Vavilova Str. 1., 308503 Belgorod district, Belgorod \\ region, Russia \\ ${ }^{2}$ Federal State Budgetary Scientific Institution "All-Russian Research Institute of Breeding" \\ Pushkinsky district, Lesnye Polyany settlement, Lenin Str., unit 13, 141212 Moscow region, Russia
}

\begin{abstract}
In these studies, it was found that seasons have a significant impact on the reproductive function of Large White boars. It was found that these indicators were the highest in winter, and the lowest in summer. Studies have also shown that the inclusion in the diet of Large White boars of the feed additive "HydroLaktiV" in a dosage of 1.0, 1.5, 2.0\% over the main diet allowed to increase both quantitative and qualitative indicators of sperm. An increase in the quantitative and qualitative sperm indicators of the studied boars in turn led to an increase in the number of piglets in these groups by $7.4,11.6,11.4 \%$, respectively; a decrease in their cost at birth by $7.0,10.4$, and $10.3 \%$ compared to the control group.
\end{abstract}

\section{Introduction}

The most important condition for increasing the productivity of pigs in industrial complexes is the intensification of their reproductive function. At present, animals with high genetic productivity potential have been created in our country and abroad $[7,12,15,16,17]$. Nevertheless, in the production conditions that have been created in our country, a sufficiently large number of animals cannot realize their genetic potential. The connection here is quite obvious - in these conditions, it is not always possible to organize, and it is not always possible to control the full value of animal feeding $[3,5,6,7,8,9,10,11,13,14,18]$.

It is especially important to provide full-value feeding of breeding animals, as their influence on the industrial herd of pigs is great. After all, with artificial insemination of pigs, the load on one stud boar per year is more than 100 sows. So, we are simply obliged to provide full-value feeding of stud boars. And this is not so difficult, because in the structure of pigs herd in an industrial pig breeding complex with a complete production cycle, the share of boars in production is only $0.1-0.3 \%[2,4,7,9,18]$.

Currently, pig breeding in the Russian Federation is represented mainly by 16 breeds, including 8 breeds raised in breeding farms: Large White - 54.1\%, Yorkshire - 21.4\%, Landrace $-16.5 \%$, Duroc $-6.2 \%$ and all other breeds occupy only $1.8 \%[1,2,4,7$,$] .$

\footnotetext{
${ }^{*}$ Corresponding author: umat_05@mail.ru
} 
Given the fact that in Russia the largest share among all breeds of pigs is occupied by a Large White breed, the study of its reproductive function and productivity in the conditions of industrial technology in the Belgorod region is an urgent issue $[3,6]$.

\section{Materials and methods of research}

The purpose of studying the Large White boar reproductive function and productivity formed the basis of special research conducted by us. So, according to the principle of analogues, 5 adult Large White boars (aged 2.0-2.5 years) were selected for the experiment. The experiment was conducted on the basis of the APC "Collective Farm n.a. Gorin" of the Belgorod region. In selected experimental boars, the reproductive function was studied according to the seasons of the year.

In the course of experiments, having received sperm from boars, quantitative and qualitative indicators were determined. Then the artificial insemination of sows was performed by the method of the All-Russian Institute of Livestock Breeding.

Results of the study and their discussion. At the start of our research, we studied the quantitative and qualitative indicators of sperm of Large White boars depending on the seasons of the year.

Quantitative indicators of Large White boar sperm are shown in table 1.

Table 1. Quantitative indicators of Large White boar sperm

\begin{tabular}{|l|c|c|c|c|c|}
\hline \multicolumn{1}{|c|}{$\begin{array}{l}\text { Season of } \\
\text { the year }\end{array}$} & $\begin{array}{c}\text { Number } \\
\text { of boars } \\
\text { in the } \\
\text { group }\end{array}$ & $\begin{array}{c}\text { Number of } \\
\text { the studied } \\
\text { ejaculates }\end{array}$ & \multicolumn{3}{|c|}{ Quantitative indicators of boar sperm } \\
\cline { 4 - 6 } & & & $\begin{array}{c}\text { Sperm } \\
\text { volume, ml }\end{array}$ & $\begin{array}{c}\text { Concentration of } \\
\text { sperm cells in 1 } \\
\text { ml. of sperm, } \\
\text { mln. }\end{array}$ & $\begin{array}{c}\text { Total number } \\
\text { of sperm cells } \\
\text { in the } \\
\text { ejaculate, } \\
\text { billion }\end{array}$ \\
\hline Winter & 5 & 30 & $326.0 \pm 8.0$ & $225.0 \pm 6.5$ & 80.1 \\
\hline Spring & 5 & 30 & $312.0 \pm 11.0$ & $208.0 \pm 7.0$ & 64.8 \\
\hline Summer & 5 & 30 & $295.0 \pm 9.5$ & $191.0 \pm 8.0$ & 56.3 \\
\hline Autumn & 5 & 30 & $310.0 \pm 12.0$ & $210.0 \pm 7.2$ & 65.1 \\
\hline $\begin{array}{l}\text { Average for } \\
\text { seasons }\end{array}$ & 5 & 120 & $318.0 \pm 9.2$ & $208.0 \pm 6.8$ & 66.1 \\
\hline
\end{tabular}

Analyzing the data in table 1 , we see that seasonality has a direct impact on the quantitative characteristics of the sperm of Large White boars. Thus, the obtained indicators were the highest in winter, and in summer they had the lowest values. At the same time, over the year, the obtained quantitative indicators of the quality of sperm of Large White boars were at the level required for this breed by the standards and fully corresponded to them.

Qualitative indicators of Large White boar sperm are shown in table 2.

Table 2. Qualitative indicators of cleanbred Large White boar sperm

\begin{tabular}{|l|c|c|c|c|c|}
\hline $\begin{array}{l}\text { Season of } \\
\text { the year }\end{array}$ & $\begin{array}{c}\text { Number of } \\
\text { boars in the } \\
\text { group }\end{array}$ & $\begin{array}{c}\text { Number of the } \\
\text { studied ejaculates }\end{array}$ & \multicolumn{3}{|c|}{ Qualitative indicators of boar sperm } \\
\cline { 4 - 6 } & & & mobility, point & resistance & $\begin{array}{c}\text { Out-of-body survival, } \\
\text { hour }\end{array}$ \\
\hline Winter & 5 & 30 & 8.4 & $1150.0 \pm 105$ & $85.0 \pm 1.5$ \\
\hline Spring & 5 & 30 & 8.2 & $1015.0 \pm 121$ & $72.0 \pm 1.8$ \\
\hline
\end{tabular}




\begin{tabular}{|l|c|c|c|c|c|}
\hline Summer & 5 & 30 & 7.9 & $850.0 \pm 125$ & $68.0 \pm 1.9$ \\
\hline Autumn & 5 & 30 & 8.1 & $1010.0 \pm 115$ & $74.0 \pm 1.4$ \\
\hline $\begin{array}{l}\text { Average } \\
\text { for seasons }\end{array}$ & 5 & 120 & 8.1 & $1006.0 \pm 118$ & $73.2 \pm 1.5$ \\
\hline
\end{tabular}

The data shown in table 2 clearly indicate that the qualitative indicators of sperm of Large White boars also depend on the seasons of the year.

Qualitative indicators of boar sperm: mobility, resistance and survival of sperm outside the body were maximal in winter, and their minimum values were observed in summer.

However, the main criterion for the quality of boar sperm is the effectiveness of artificial insemination of sows. Considering this, we conducted artificial insemination of sows after establishing quantitative and qualitative indicators of boar sperm. The results obtained as a result of artificial insemination of sows are shown in table 3.

Table 3. Effectiveness of artificial insemination of sows with sperm of Large White boars

\begin{tabular}{|c|c|c|c|c|c|c|}
\hline Season & \multirow{2}{*}{$\begin{array}{c}\text { Number } \\
\text { of the } \\
\text { studied } \\
\text { ejaculates }\end{array}$} & \multicolumn{2}{|l|}{ Of them farrowed } & \multicolumn{2}{|c|}{ Piglets received, head } & $\begin{array}{c}\text { Weight of 1 pig } \\
\text { at birth }\end{array}$ \\
\cline { 3 - 6 } & & number & $\%$ & number & $\%$ & \\
\hline Winter & 30 & 27 & 90.0 & 338 & $12.5 \pm 0.3$ & $1.27 \pm 0.02$ \\
\hline Spring & 30 & 26 & 86.6 & 292 & $11.2 \pm 0.4$ & $1.28 \pm 0.02$ \\
\hline Summer & 30 & 21 & 70.0 & 221 & $10.5 \pm 0.3$ & $1.27 \pm 0.02$ \\
\hline Autumn & 30 & 25 & 83.3 & 275 & $11.0 \pm 0.2$ & $1.29 \pm 0.02$ \\
\hline $\begin{array}{c}\text { Average for } \\
\text { seasons }\end{array}$ & 120 & 99 & 82.5 & 1126 & $11.3 \pm 0.3$ & $1.28 \pm 0.02$ \\
\hline
\end{tabular}

Table 3 shows that the influence of seasonality affects not only the sperm production of boars, but also the effectiveness of artificial insemination of sows. It should be noted that the difference in such indicators as fertilization and sow prolificacy by season is significant. So, in the winter period, fertilization and prolificacy were maximum, respectively $90.0 \%$ and 12.5 piglets, which is more than in the summer period, respectively, by 20.0 and $10.0 \%$. On average, for all seasons of the year, the fertilization and sow prolificacy was $82.5 \%$ and 11.3 piglets. These are satisfactory indicators, but taking into account the fact that the APC "Collective Farm n.a. Gorin" has been approved as a breeding farm for Large White pigs, and these indicators should be higher.

It is known that to improve the reproductive function of boars is possible not only through breeding but also by increasing the usefulness of their feeding. This statement has been proven in studies by many authors (V.P. Kononov, 1982, 1990; Pokhodnya G.S., 1988, 1990, 1995, 2002, 2004, 2009, 2011, 2019; E.G. Fedorchuk, 2006,2009,2011; A.Yu. Kalinin, 2019, 2020; A.T. Mysik et al., 2019, 2020, etc.). Having studied a large number of literary sources, we noted the studies of E.G. Fedorchuk $(2011,2016)$, who in her works conducted a study of the using effectiveness of feed additive "HydroLaktiV" in order to increase the reproductive function of Landrace boars.

Based on these developments, we decided to study how feeding the feed additive "HydroLaktiC" to Large White boars affects their reproductive function and productivity.

For research, we selected 4 groups of Large White boars. In this experiment, the boars of the first control group received only the main diet (3.5 $\mathrm{kg}$ of mixed feed SK-1), and the boars of the second, third and fourth groups in addition to the main diet received a feed additive "HydroLaktiV" in the amount of 1.0, 1.5, 2.5\%. Previously, it was established that boar reproductive function is affected by seasonality, for this reason, as in the first experiment, we carried out our research in the winter, spring, summer and autumn periods. So, the 
quantitative indicators of sperm of Large White boars obtained in the winter period are shown in table 4.

Table 4. Quantitative indicators of sperm of Large White boars depending on feeding them with feed additive "HydroLaktiV" in the winter period

\begin{tabular}{|c|c|c|c|c|c|c|}
\hline \multirow{2}{*}{\begin{tabular}{|c|}
$\begin{array}{c}\text { Experimental } \\
\text { groups }\end{array}$ \\
\end{tabular}} & \multirow{2}{*}{\begin{tabular}{|c|} 
Amount of \\
feed additive \\
"HydroLakti \\
V" in boar \\
diet, \%
\end{tabular}} & \multirow{2}{*}{$\begin{array}{l}\text { Number of } \\
\text { boars in the } \\
\text { group }\end{array}$} & \multirow{2}{*}{$\begin{array}{c}\text { Number of } \\
\text { ejaculates } \\
\text { studied }\end{array}$} & \multicolumn{3}{|c|}{ Quantitative indicators of sperm } \\
\hline & & & & volume, $\mathrm{ml}$ & $\begin{array}{c}\text { Concentration, } \\
\text { million } / \mathrm{ml}\end{array}$ & $\begin{array}{l}\text { Total number of } \\
\text { sperm cells in the } \\
\text { ejaculate, billion }\end{array}$ \\
\hline 1 & 0 & 3 & 18 & $352.0 \pm 9.0$ & $228.0 \pm 8.0$ & 80.2 \\
\hline 2 & 1.0 & 3 & 18 & $358.0 \pm 7.0$ & $245.0 \pm 10.0$ & 87.7 \\
\hline 3 & 1.5 & 3 & 18 & $362.0 \pm 6.0$ & $248.0 \pm 7.5$ & 89.7 \\
\hline 4 & 2.0 & 3 & 18 & $365.0 \pm 8.0$ & $254.0 \pm 8.3$ & 92.7 \\
\hline
\end{tabular}

Analyzing the data in table 4, we see that feeding with the feed additive "HydroLaktiV" to boars in a dosage of $1.0 ; 1.5 ; 2.0 \%$ over the main dose in winter allows to increase the quantitative indicators of sperm of Large White boars. Thus, the volume of sperm in the experimental groups (2-4 groups) increased by $7.4 ; 8.7 ; 11.4 \%$, respectively, and the total number of sperm in ejaculates increased by $9.3 ; 11.8 ; 15.5 \%$ compared to the first control group, respectively.

Quantitative indicators of sperm of Large White boars obtained in the spring period, depending on feeding them with the feed additive "HydroLaktiV" are shown in table 5.

Table 5. Quantitative indicators of sperm of Large White boars depending on feeding them with feed additive "HydroLaktiV" in the spring period

\begin{tabular}{|c|c|c|c|c|c|c|}
\hline $\begin{array}{c}\text { Experime } \\
\text { ntal } \\
\text { groups }\end{array}$ & $\begin{array}{c}\text { Amount of } \\
\text { feed additive } \\
\text { "HydroLaktiV } \\
\text { " in boar diet, } \\
\%\end{array}$ & $\begin{array}{c}\text { Number of } \\
\text { boars in the } \\
\text { group }\end{array}$ & $\begin{array}{c}\text { Number of } \\
\text { ejaculates } \\
\text { studied }\end{array}$ & \multicolumn{3}{|c|}{ Quantitative indicators of sperm } \\
\cline { 5 - 7 } & 0 & 3 & 18 & $311.0 \pm 8.0$ & $212.0 \pm 9.0$ & volume, ml \\
\hline 1 & 1.0 & 3 & 18 & $324.0 \pm 9.0$ & $227.0 \pm 10.1$ & 74.6 \\
\hline 2 & 1.5 & 3 & 18 & $336.0 \pm 8.0$ & $231.0 \pm 12.0$ & 77.9 \\
\hline 3 & 2.0 & 3 & 18 & $340.0 \pm 6.0$ & $244.0 \pm 9.0$ & 82.2 \\
\hline 4 & & & & & \\
\hline
\end{tabular}

Data from table 5 show that the quantitative indicators of sperm of Large White boars in the spring period decrease compared to the winter period, both in the control group and in the experimental groups. However, it should be noted that the introduction of the feed additive "HydroLaktiV" into the diet of boars of this breed still increases the quantitative indicators of boar sperm in comparison with the control group. Thus, the volume of sperm in the second, third and fourth groups increased by $4.2 ; 7.7 ; 8.9 \%$, respectively, the concentration of sperm cells in $1 \mathrm{ml}$ of sperm in similar groups increased by $7.1 ; 8.9 ; 15.1$ $\%$, respectively, the total number of sperm cells in ejaculates increased by $14.7 ; 20.6 ; 27.2 \%$ compared to the first, control group, respectively.

Data on the quantitative indicators of sperm of experimental Large White boars, which were obtained by us in the summer period, are shown in table 6 . 
Table 6. Quantitative indicators of sperm of Large White boars depending on feeding them with feed additive "HydroLaktiV" in the summer period

\begin{tabular}{|c|c|c|c|c|c|c|}
\hline $\begin{array}{c}\text { Experimen } \\
\text { tal groups }\end{array}$ & $\begin{array}{c}\text { Amount of } \\
\text { feed additive } \\
\text { "HydroLakti } \\
\text { V" in boar } \\
\text { diet, \% }\end{array}$ & $\begin{array}{c}\text { Number of } \\
\text { boars in the } \\
\text { group }\end{array}$ & $\begin{array}{c}\text { Number of } \\
\text { ejaculates } \\
\text { studied }\end{array}$ & \multicolumn{4}{|c|}{ Quantitative indicators of sperm } \\
\cline { 5 - 7 } & & & & & & \\
\hline 1 & 0 & 3 & 18 & $291.0 \pm 11.0$ & $202.0 \pm 7.0$ & 58.8 \\
\hline 2 & 1.0 & 3 & 18 & $312.0 \pm 8.0$ & $220.0 \pm 9.2$ & 68.5 \\
\hline 3 & 1.5 & 3 & 18 & $324.0 \pm 6.0$ & $226.0 \pm 5.0$ & 73.3 \\
\hline 4 & 2.0 & 3 & 18 & $337.0 \pm 6.5$ & $238.0 \pm 7.0$ & 80.1 \\
\hline
\end{tabular}

Table 6 shows that the quantitative indicators of sperm of Large White boars in the summer period are even more reduced in all groups compared to the winter and spring periods. However, in the experimental groups (2-4 groups), this decrease is less, apparently due to more full-value feeding of boars. So, in Large White boars in the experimental groups (groups 2-4), these indicators were as follows: the volume of sperm increased by $8.9 ; 11.8$; $17.8 \%$, respectively, and the total number of sperm cells in ejaculates increased by $16.5 ; 24.6$; $36.2 \%$ compared to the first control group, respectively.

Data on the quantitative indicators of sperm of Large White boars depending on the introduction of the feed additive "HydroLaktiV" into their diet, which were obtained in the autumn period, are reflected in table 7 .

Table 7. Quantitative indicators of sperm of Large White boars depending on feeding them with feed additive "HydroLaktiV" in the autumn period

\begin{tabular}{|c|c|c|c|c|c|c|}
\hline \multirow{2}{*}{\begin{tabular}{|l} 
Experimen \\
tal groups
\end{tabular}} & \multirow{2}{*}{$\begin{array}{c}\text { Amount of } \\
\text { feed additive } \\
\text { "HydroLaktiV" } \\
\text { in boar diet, \% }\end{array}$} & \multirow{2}{*}{$\begin{array}{c}\text { Number of } \\
\text { boars in the } \\
\text { group }\end{array}$} & \multirow{2}{*}{$\begin{array}{c}\text { Number of } \\
\text { ejaculates } \\
\text { studied }\end{array}$} & \multicolumn{3}{|c|}{ Quantitative indicators of sperm } \\
\hline & & & & volume, $\mathrm{ml}$ & $\begin{array}{l}\text { Concentration, } \\
\text { million } / \mathrm{ml}\end{array}$ & $\begin{array}{l}\text { Total number of } \\
\text { sperm cells in the } \\
\text { ejaculate, billion }\end{array}$ \\
\hline 1 & 0 & 3 & 18 & $308.0 \pm 10.0$ & $215.0 \pm 8.0$ & 66.2 \\
\hline 2 & 1.0 & 3 & 18 & $315.0 \pm 12.0$ & $228.0 \pm 11.0$ & 71.8 \\
\hline 3 & 1.5 & 3 & 18 & $334.0 \pm 8.0$ & $235.0 \pm 6.0$ & 78.4 \\
\hline 4 & 2.0 & 3 & 18 & $345.0 \pm 7.0$ & $240.0 \pm 9.0$ & 82.2 \\
\hline
\end{tabular}

Table 7 shows that the quantitative indicators of sperm of Large White boars are almost similar to those in the spring period, both in the control group and in the experimental groups. If we compare the main indicator-the total number of sperm cells in ejaculates in spring and autumn in the control group, this indicator looks like this: 65.4 billion. in the spring and 66.2 billion in autumn (1.2\% difference). And if to compare this indicator in the best experimental group (group 4), there will be an even smaller difference.

And if to compare this indicator in the best experimental group (group 4), there will be an even smaller difference: in the spring - 83.2 billion, in the autumn - 82.8 billion (the difference is only $0.4 \%$ ). However, we should note that in the autumn period, feeding with the feed additive "HydroLaktiV" to Large White boars had a positive effect on the quantitative indicators of sperm of Large White boars. For example, in the second, third and fourth groups, the volume of sperm increased by $2.2 ; 8.4 ; 12.0 \%$, respectively; the concentration of sperm cells in $1 \mathrm{ml}$ of sperm increased by $6.0 ; 9.3 ; 11.6 \%$, respectively; the 
total number of sperm cells in ejaculates increased by $8.4 ; 18.4 ; 25.0 \%$, respectively, compared to the control group.

In order to objectively assess the effect of feeding with the feed additive "HydroLaktiV" on the quantitative indicators of sperm of Large White boars, we present the data obtained during the experiments of these indicators for all seasons of the year in table 8 .

Table 8. Quantitative indicators of sperm of Large White boars depending on feeding them with feed additive "HydroLaktiV" (for all seasons of the year)

\begin{tabular}{|c|c|c|c|c|c|c|}
\hline \multirow{2}{*}{$\begin{array}{c}\text { Experimental } \\
\text { groups }\end{array}$} & \multirow{2}{*}{$\begin{array}{c}\text { Amount of } \\
\text { feed additive } \\
\text { "HydroLaktiV" } \\
\text { in boar diets, } \\
\%\end{array}$} & \multirow{2}{*}{$\begin{array}{l}\text { Number of } \\
\text { boars in the } \\
\text { group }\end{array}$} & \multirow{2}{*}{$\begin{array}{c}\text { Number of } \\
\text { ejaculates } \\
\text { studied }\end{array}$} & \multicolumn{3}{|c|}{ Quantitative indicators of sperm } \\
\hline & & & & volume, $\mathrm{ml}$ & $\begin{array}{c}\text { Concentration, } \\
\text { million } / \mathrm{ml}\end{array}$ & $\begin{array}{c}\text { Total number of } \\
\text { sperm cells in the } \\
\text { ejaculate, billion }\end{array}$ \\
\hline 1 & 0 & 3 & 72 & 315.0 & 214.0 & 67.6 \\
\hline 2 & 1.0 & 3 & 72 & 327.5 & 230.2 & 75.5 \\
\hline 3 & 1.5 & 3 & 72 & 339.0 & 235.2 & 79.8 \\
\hline 4 & 2.0 & 3 & 72 & 347.0 & 244.0 & 84.7 \\
\hline
\end{tabular}

Analyzing the generalized data of quantitative indicators of sperm of Large White boars when feeding them with the feed additive "HydroLaktiV" by seasons, it is important to note the following: feeding with the feed additive "HydroLaktiV" in the amount of $1.0 ; 1.5 ; 2.0 \%$ in addition to the main diet of Large White boars leads to an increase in such indicators as the volume of ejaculates by $3.9 ; 7.6 ; 10.1 \%$, respectively, the concentration of sperm cells in $1 \mathrm{ml}$ of sperm by $11.6 ; 18.0 ; 25.2 \%$, respectively, in comparison with the control group.

It should be noted that not only quantitative indicators of boar sperm play an important role for the effectiveness of artificial insemination of sows. Qualitative indicators, such as sperm cells mobility, resistance and survival of sperm cells outside the body, are also of great importance. We also studied these indicators in our research.

The complex of studies conducted by us showed the following: the introduction of the feed additive "HydroLaktiV" in the diet of Large White boars in the amount of $1.0 ; 1.5 ; 2.0 \%$ over the main daily diet gives an increase in sperm mobility by $1.2 ; 2.4 ; 2.4 \%$, respectively, and sperm cells resistance by $6.7 ; 10.5 ; 11.9 \%$. Such an indicator as the survival of sperm cells outside the body also increased in its values by $4.6 ; 11.4 ; 13.6 \%$, respectively, compared to the first control group.

Attaching great importance to the quantitative and qualitative indices of boar sperm, we should know that the main criterion of biological value of boar sperm, along with the intensification of their reproductive function is the fertilizing ability of the sperm cells and the final factor - the number of received piglets.

Therefore, after receiving and evaluating the quality of sperm from experimental boars, we performed artificial insemination of sows in all seasons of the year. Here, also, the best performance indicators of artificial insemination of sows were recorded in winter, while in summer the situation is reversed - the indicators were the worst.

Table 9 shows the results of artificial insemination of sows for all seasons, depending on the feeding of feed additives to boars. 
Table 9. Effectiveness of insemination of sows with the sperm of Large White boars, depending on feeding them with the feed additive "HydroLaktiV" (for all seasons of the year)

\begin{tabular}{|c|c|c|c|c|c|c|c|}
\hline \multirow{2}{*}{$\begin{array}{c}\text { Experimen } \\
\text { tal groups }\end{array}$} & $\begin{array}{c}\text { Number of the } \\
\text { studied } \\
\text { ejaculates }\end{array}$ & $\begin{array}{c}\text { Number of } \\
\text { inseminated } \\
\text { sows, head }\end{array}$ & \multicolumn{2}{|l|}{ Of them farrowed } & \multicolumn{2}{|l|}{ Piglets received, head } & \multirow{2}{*}{$\begin{array}{c}\text { Heavy litter, } \\
\mathrm{kg}\end{array}$} \\
\cline { 4 - 7 } & & & number & $\%$ & total & per 1 farrow & \\
\hline 1 & 0 & 120 & 98 & 81.6 & 1060 & 10.81 & 1.28 \\
\hline 2 & 1.0 & 120 & 103 & 85.8 & 1139 & 11.05 & 1.28 \\
\hline 3 & 1.5 & 120 & 104 & 86.6 & 1183 & 11.37 & 1.27 \\
\hline 4 & 2.5 & 120 & 104 & 86.6 & 1181 & 11.35 & 1.27 \\
\hline
\end{tabular}

The data obtained for all seasons of the year (table 9) tell us that feeding the feed additive "HydroLaktiV" to Large White boars in the amount of $1.0 ; 1.5 ; 2.0 \%$ in addition to the main diet has a positive effect and increases: fertilization by $4.2 ; 5.0 ; 5.0 \%$, respectively; sow prolificacy by $2.2 ; 5.1 ; 4.9 \%$, respectively, in comparison with the control group. These studies have shown that the seasons of the year affect in a certain way the quantitative and qualitative indicators of sperm, and ultimately the effectiveness of artificial insemination of sows. However, in our research, we found that feeding a certain amount of "HydroLactiV" feed additive to Large White boars in all seasons of the year had a positive effect on the reproductive function and productivity of boars. Based on these data, it can be concluded that using certain factors, such as feeding, maintenance, and others, in production conditions, it is possible to reduce the negative impact of seasonality on the reproductive function and productivity of stud boars.

Summing up the results of biological and zootechnical indicators obtained in our experiments, we must justify them for objective recommendations to production from an economic point of view, namely, to establish the economic efficiency of using the feed additive "HydroLaktiV" in the diets of Large White boars. We performed these calculations in table 10 .

Table 10. Effectiveness of using the feed additive "HydroLaktiV" in the diets of Large White boars

\begin{tabular}{|c|c|c|c|c|}
\hline \multirow[t]{2}{*}{ Indicators } & \multicolumn{4}{|c|}{ Boars feeding conditions } \\
\hline & $\begin{array}{l}\text { Basic diet }(3,5 \\
\mathrm{kg} \text { of compound } \\
\text { feed SK-1) }\end{array}$ & $\begin{array}{l}\text { BD }+1.0 \% \text { of } \\
\text { the feed additive } \\
\text { "HydroLaktiV" }\end{array}$ & $\begin{array}{l}\text { BD }+1.5 \% \text { of } \\
\text { the feed additive } \\
\text { "HydroLaktiV" }\end{array}$ & $\begin{array}{l}\text { BD }+2.0 \% \text { of } \\
\text { the feed additive } \\
\text { "HydroLaktiV" }\end{array}$ \\
\hline Number of boars in the group & 3 & 3 & 3 & 3 \\
\hline $\begin{array}{l}\text { Duration of the trial period, } \\
\text { days }\end{array}$ & 120 & 120 & 120 & 120 \\
\hline $\begin{array}{l}\text { Total cost per } 1 \text { boar for the } \\
\text { trial period, RUB. }\end{array}$ & 7800.0 & 7800.0 & 7800.0 & 7800.0 \\
\hline $\begin{array}{l}\text { The cost of the feed additive } \\
\text { "HydroLaktiV" per } 1 \text { boar for } \\
\text { the experimental period, RUB. }\end{array}$ & 0 & 420.0 & 630.0 & 840.0 \\
\hline $\begin{array}{l}\text { Sperm doses obtained from } 1 \\
\text { boar per experimental period }\end{array}$ & 438 & 495 & 530 & 562 \\
\hline Cost of 1 sperm dose, RUB. & 17.80 & 15.75 & 14.71 & 13.87 \\
\hline $\begin{array}{l}\text { Cost of maintaining } 120 \text { sows } \\
\text { (gestation period, } 115 \text { days), } \\
\text { RUB. }\end{array}$ & 690000.0 & 690000.0 & 690000.0 & 690000.0 \\
\hline $\begin{array}{l}\text { Costs for double insemination } \\
\text { of } 120 \text { sows, RUB. }\end{array}$ & 4272.00 & 3780.00 & 3530.40 & 3328.80 \\
\hline $\begin{array}{l}\text { Total costs for received piglets } \\
\text { of } 120 \text { inseminated sows, RUB. }\end{array}$ & 694272.0 & 693780.0 & 693530.4 & 693328.8 \\
\hline
\end{tabular}




\begin{tabular}{|l|c|c|c|c|}
\hline $\begin{array}{l}\text { Number of piglets obtained } \\
\text { from } 120 \text { inseminated sows, } \\
\text { head }\end{array}$ & 1060 & 1139 & 1183 & 1181 \\
\hline Cost of 1 pig at birth, RUB. & 654.97 & 609.11 & 586.24 & 587.06 \\
\hline trelative to the first group, \% & 0 & -7.0 & -10.4 & -10.3 \\
\hline
\end{tabular}

Data analysis of table 10 allows us to conclude that feeding boars with feed additive "HydroLactiV" in the amount of 1,$0 ; 1,5 ; 2,0 \%$ in addition to the daily diet leads to an increase in the number of sperm doses per 1 boar for experienced period 13.0;21,0;28.3\% respectively, as well as to reduce the cost 1 sperm dose in the experimental groups (groups $2-4), 11.5 ; 17,3 ; 22,0 \%$ respectively compared to the control group. However, these positive indicators of boar sperm production can not be final for determining the effectiveness of the use of the feed additive "HydroLaktiV" in boar diets. The final criteria for developing recommendations for production, as is known, can be: the number of piglets received and their cost at birth. Taking these positions into account, we also received positive indicators in our research. In particular, due to the improvement of quality indicators in our experiments in experimental groups (2-4 groups), we were able to increase the fertilization and sow prolificacy, and this in turn affected the increase in the number of piglets received from 120 inseminated sows by $7.4,11.6,11.4 \%$, respectively. At the same time, in comparison with the control (first) group, there was a decrease in the cost of 1 pig at birth by $7.0 ; 10.4 ; 10.3 \%$, respectively.

From this it follows that our research has shown the following: the introduction of the feed additive "HydroLaktiV" in addition to the main diet of Large White boars in different dosages has a positive effect on the quantitative indicators of sperm, which made it possible to increase the number of sperm doses and reduce their cost. In turn, an increase in the quality of sperm from experimental boars in the experimental groups led to an increase in the fertilization rate and sow prolificacy.

This had a positive effect on the total number of piglets received from 120 inseminated sows. In addition, their cost at birth in the experimental groups decreased by $7.0,10.4$, and $10.3 \%$, respectively, compared to the control group.

Based on this, it should be noted that in terms of economic efficiency and zootechnical parameters, the best of all tested options should be considered the option with feeding the feed additive "HydroLaktiV" to Large White boars in all seasons of the year in an amount of $1.5 \%$ in addition to the main diet.

\section{References}

1. S.N. Aleynik, G.S. Pokhodnya, A.N. Dobudko, Reproductive function and productivity of purebred and local Large White and Yorkshire boars, (Belgorod: LLC RPC "Polyterra", 2020)

2. S.N. Aleynik, G.S. Pokhodnya, A.A. Novikov, S.M. Mirzaev, Fundamentals of breeding in pig farming (LLC RPC "Polyterra", 2020)

3. I.F. Gorlov, L.A. Breusova, Bulletin of the Russian Academy of Agricultural Sciences, 1, $31(2013)$

4. G.S. Pokhodnya, M.M. Moroz, Zootechny, 6, 31 (2007)

5. Yu.P. Breslavets, Growth, development and meat qualities of pigs when feeding them with Chlorella suspension (Belgorod: Belgorod SAU, 2015)

6. N.I. Zhernakova, A.N. Dobudko, T.A. Malakhova et al., Optimization of housing of single sows during their preparation for insemination (Belgorod: Belgorod SAU, 2016) 
7. G.S. Pokhodnya, Pig Breeding, Reproduction and breeding in pig farming, 1, 768 (Belgorod: publishing house of the RPC "Polyterra", 2019)

8. A.T. Mysik, G.S. Pokhodnya, T.A. Malakhova [et al.], Zootechny, 3, 24-28 (2020)

9. G.I Gorshkov, A.G. Narizhny, E.G. Fedorchuk, Zootechny, 5, 8-10 (2014)

10. L.N. Gamko, D.K. Ufimtsev, Forage Production, 2, 45-46 (2011)

11. A.T. Mysik, N.N. Sorokina, N.B. Ordina, V.N. Seleznev, A.V. Sergienko, Zootechny, 12, 14-17 (2019)

12. John. A. Beck, PLOS ONE, 5(5), 10-16 (2018)

13. J. Lewis, J. Abas, C. Dadousis, et al., PLOS ONE, 6(4), 18-27 (2015)

14. E. Seroussi, Glick., A. Shirak et al., BMC Genomics, 11, 673-701 (2015)

15. J. Weller, M. Ron, Dairy Sci., 94(3), 1082-1090 (2016)

16. M. Gautier, Denis Laloë, Katayoun Moazami-Goudarzi, PLOS ONE, 5(9), 13-38 (2016)

17. V.P. Zhabinskaya, N.S. Trubchaninova, G.S. Pokhodnya, D.V. Korobov, V.I. Kotarev, O.E. Tat'yanicheva, N.B. Ordina, International of Advanced Biotechnology and Research, 10(1), 47-53 (2019) 